\title{
Pengetahuan Pelaku Illegal Logging tentang Hutan
}

\author{
Drefika Putra ${ }^{1}$, Erda Fitriani ${ }^{2}$ \\ ${ }^{1,2}$ Universitas Negeri Padang, Padang \\ Email: drefikaputra@yahoo.com; fitriani_cim@fis.unp.ac.id
}

\begin{abstract}
Abstrak
Masalah kerusakan hutan tidak hanya semata masalah alamiah, akan tetapi ada faktor manusia yang menjadi aktor dibelakangnya. Para illegal loging sebagai salah satu aktor yang melakukan aktivitas penebangan hutan illegal, perlu digali pengetahuan mengenai hutan dan lingkunganya. Lokasi penelitian yaitu Nagari Unggan Kecamatan Sumpur Kudus Kabupaten Sijunjung. Sumatera Barat. Penelitian dilakukan dengan pendekatan kualitatif tipe etnografi. Peneliti melakukan observasi partisipasi aktif dengan mengikuti penebang hutan dan melakukan wawancara mendalam dengan penebang hutan dan tokoh masyarakat nagari. Hasil penelitian memperlihatkan pengetahuan pelaku illegal logging terhadap hutan di Nagari Unggan. Pengetahuan yang dimiliki oleh illegal loging merupakan pengetahuan yang diperoleh sebagai bagian dari anggota masyarakat dan budaya setempat, seperti pengetahuan mengenai batasan hutan, ritual-ritual di dalam hutan, jenis-jenis pohon dalam hutan, serta pantangan-pantangan perilaku ketika berada di dalam hutan. Selain itu pengetahuan yang dimilikinya sebagai pelaku illegal loging yang melahirkan pengetahuan yang khas, sebagai strategi dalam hidupnya. Pelaku illegal logging menganggap hutan sebagai sumber uang, pekerjaan mereka memiliki tantangan mempertaruhkan nyawa, dan bekerja sama dengan oknum. Pengetahuan pelaku illegal logging (pekerja somel) terhadap hutan merupakan hasil interprestasi mereka dari pengalaman selama bekerja sebagai pekerja somel.
\end{abstract}

Kata kunci: Antropologi kognitif, Hutan, Illegal loging, Pengetahuan

\section{Abstract}

The problem of forest destruction is not only a natural problem, but there are also human factors who are the actors behind it. Illegal loggers, as actors carrying out illegal logging activities, need to have their knowledge of the forest and its environment studied. The research location is Nagari Unggan, Sumpur Kudus District, Sijunjung Regency. West Sumatra. The research was conducted with a qualitative ethnographic type approach. Researchers conducted active participatory observations by following forest cutters and conducting in-depth interviews with forest loggers and village community leaders. The results showed the knowledge of the perpetrators of illegal logging against the forest in Nagari Unggan. The knowledge possessed by illegal logging is knowledge obtained as part of members of the community and local culture, such as knowledge about forest boundaries, rituals in the forest, tree types in the forest, and taboo behavior when in the forest. Apart from that, the knowledge he has as an illegal logging actor gives birth to unique knowledge as a strategy in his life. Illegal logging perpetrators consider the forest as a source of money, their work has the challenge of risking their lives, and working with unscrupulous people. The knowledge of illegal logging perpetrators ("somel" workers) about the forest is the result of their interpretation from their experiences while working as "somel" workers.

Keywords: Cognitive anthropology, Forest, Illegal logging, Knowledge

\begin{tabular}{l|l|l} 
Received: December 8, 2020 & Revised: December 29, 2020 & Published: December 30, 2020
\end{tabular}

Culture \& Society: Journal of Anthropological Research Vol. 2, No. 2, Th. 2020 


\section{Pendahuluan}

Hutan Indonesia merupakan salah satu paru-paru dunia. Luas hutan Indonesia menurut data Departemen Kehutanan adalah 130 juta ha atau sebanding dengan 70\% luas Indonesia namun kondisi saat ini 42 juta ha hutan Indonesia sudah tidak berpohon lagi alias gundul. Hutanhutan di Indonesia memasuki fase rawan, kerusakannya sudah pada titik kritis. Seluruh jenis hutan di Indonesia mengalami Seluruh jenis hutan di Indonesia mengalami pembalakan liar sekitar 7,2 ha hutan per menitnya atau 3,8 juta ha hutan per tahun. Kondisi ini tidak saja mengancam keaneka ragaman hayati yang ada di dalamnya namun juga akan menimbulkan efek berantai negatif pada keseimbangan alam itu sendiri (www.beritakota.net/indeks.php/ 2010/05/03).

Awalnya masalah kerusakan hutan merupakan masalah alami, yakni peristiwa-peristiwa yang terjadi sebagai bagian dari proses natural, proses natural ini terjadi tanpa menimbulkan akibat berarti bagi, dan dapat pulih kemudian secara alami (homeostasi). Akan tetapi, sekarang masalah kerusakan hutan tidak dapat dikatakan sebagai masalah-masalah yang semata-mata bersifat alami, karena manusia memberikan faktor penyebab sangat signifikan bagi lingkungan (Http://grennch.multiply.com/journal/item/8). Jika sikap dan pengetahuan masyarakat rendah terhadap kelestarian hutan maka berdampak kurangnya kepedulian mereka terhadap hutan, begitu juga sebaliknya jika pengetahuan dan sikap masyarakat tinggi terhadap hutan maka kawasan hutan dapat terjaga kelestariannya dengan baik (Haffar, 1997).

Illeggal logging juga terjadi di Sumatera Barat, karena potensi kayu yang terdapat di kawasan hutan Minangkabau ini juga cukup besar. Terdapat berbagai jenis kayu dan berkualitas tinggi, seperti; rasak yang kualitasnya dianggap sama dengan kayu jati, meranti, banio, surian, dan sebagainya. Berbagai jenis kayu ini sudah dieksploitasi baik untuk menunjang kebutuhan domestik maupun untuk diekspor. Berbagai kekayaan sumber daya hutan tersebut, telah menarik perhatian para pengusaha untuk melakukan eksploitasi berbagai sumber daya hutan dalam skala besar (Asoka, 2011). Daerah-daerah di pulau Sumatera termasuk daerah yang memiliki hutan yang luas dengan pohon-pohon relatif besar sebagai salah satu komoditi penghasil kayu yang tak luput dari pembalakan liar.

Kabupaten Sijunjung merupakan salah satu dari 19 kota dan kabupaten yang memiliki hutan terluas di Sumatera Barat yaitu 221.191,77 ha (http://www.sijunjung.go.id), hutan yang luas tersebut sebagian besar telah dirusak karena aktivitas pengambilan kayu (Wawancara Edi Warman (42 tahun) anggota UPPL Nagari Unggan). Sejak tahun 1991 hutan di Kabupaten Sijunjung sampai sekarang yang seharusnya dijaga karena hutan menjadi penjaga persediaan air dan tempat tinggal beragam hayati terancam punah karena illeggal logging dan pembalakan liar yang terjadi membuat sebagian hutan di daerah Sijunjung rusak.

Beberapa kerusakan hutan di Nagari Unggan Kecamatan Sumpur Kudus disebabkan oleh kegiatan illegal logging di hulu sungai sehingga kawasan tersebut tidak dapat menahan beban air yang cukup besar, maka hal ini dapat menyebabkan terjadinya banjir (Wawancara Edi Warman (42 tahun) anggota UPPL Nagari Unggan). Penebangan hutan di daerah Sijunjung dilakukan oleh masyarakat setempat, mereka menebang hutan untuk diambil kayunya, hal ini mereka lakukan sebagai mata pencaharian masyarakat yang tinggal di sekitar hutan. Aktivitas-aktivitas seperti ini ternyata berdampak pada keseimbangan alam, yang mengakibatkan beberapa bencana alam terjadi di Nagari Unggan Kecamatan Sumpur Kudus Kabupaten Sijunjung (Wawancara dengan sekretaris wali Nagari Unggan Haffan Hadid 26 tahun). Banjir yang terjadi di Nagari Unggan disebabkan oleh aktivitas masyarakat yang menebang hutan di daerah hulu sungai. Daerah hulu sungai terletak di kawasan hutan yang banyak ditumbuhi oleh pohon-pohon besar. Di dalam kurun waktu 20 tahun terakhir terjadi peningkatan banjir, di sisi lain jumlah somel yang ada di Nagari Unggan juga bertambah. Adanya pengolahan kayu di hutan secara besar-besaran oleh somel (1stilah daerah untuk illegal logging) telah mengurangi jumlah daerah serapan di hulu sungai. Bencana yang terjadi karena pengambilan kayu di hutan lindung dilakukan oleh beberapa sawmill

Culture \& Society: Journal of Anthropological Research Vol. 2, No. 2, Th. 2020 
(gergaji selendang) (http://proseskayu.blogspot.com/2012), oleh masyarakat Nagari Unggan menyebut alat ini dengan somel.

Sistem pengetahuan adalah seperangkat pengetahuan, yang merupakan pengetahuan yang khas dari suatu masyarakat, karena berbeda dengan pengetahuan masyarakat yang lain. Artinya masyarakat yang berada di sekitar hutan akan memahami hutan sebagai mana pemahaman yang mereka dapat dari pengalaman hidup selama ini, pengalaman tersebut didapat dari proses belajar yang disosialisasikan oleh masyarakat lokal setempat.

Pengetahuan para pemilik dan pekerja somel dalam hal memahami hutan dan kehidupan alam yang ada di daerahnya dapat berbeda-beda, namun peneliti membatasi pada pengetahuan dari pelaku illegal logging. Untuk itu peneliti tertarik untuk mengkaji pengetahuan masyarakat Nagari Unggan khususnya pelaku Ilegal logging Kecamatan Sumpur Kudus Kabupaten Sijunjung terhadap hutan. Sebagian besar kehidupan sosial dan ekonomi masyarakat Nagari Unggan sangat tergantung pada hutan, namun di sisi lain pengambilan dan pengelolaan kayu yang dilakukan masyarakat guna mencukupi kebutuhan hidup membawa dampak jangka panjang (kerusakan ekosistem), maupun jangka pendek seperti banjir dan tanah longsor akibat hutan di daerah hulu telah dibabat untuk dijadikan komoditi kayu. Munculnya kegiatan illegal logging di Nagari Unggan karena pekerjaan sebagai pemilik dan pekerja somel ini sangat memiliki keuntungan yang sangat besar dibandingkan bekerja sebagai petani karet. Bekerja sebagai pekerja somel ini bisa menerima gaji setiap hari, sedangkan bekerja sebagai petani karet tidak bisa menerima gaji setiap hari dan kalau hari hujan tidak bisa bekerja, karena kalau hari hujan karet tidak bisa diolah karena hari hujan karet akan mencair, karena hal ini masyarakat Nagari Unggan yang awalnya bekerja sebagai petani karet dan sekarang banyak bekerja sebagai pekerja somel.

Ada banyak kajian mengenai permasalahan hutan khususnya di Indonesia, karena Indonesia sebagai salah satu negara di dunia yang memiliki jumlah hutan terluas setelah Brazil dan Afrika selatan. Tidak salah Indonesia mendapat julukan sebagai salah satu paru-paru dunia namun melihat kondisi hutan Indonesia belakangan ini yang sangat memprihatinkan. Salah satu kajian yang membahas tentang kerusakan hutan di Indonesia adalah Ratih Komala tentang "Perilaku Masyarakat Terhadap Hutan Hulu DAS Batang Kuranji Batu Busuk Kecamatan Pauh Kota Padang" Berdasarkan hasil penemuan dan pembahasan dari penelitian adalah sebagai berikut: (1). Masyarakat sudah mulai menyadari pentingnya hutan bagi kehidupan mereka, mereka mau bekerja sama dengan pemerintah dalam mengelolah hutan, namun kendala pada permasalahan hutan masih menjadi sumber mata pencaharian bagi masyarakat sehingga pengalihan fungsi lahan hutan menjadi lahan pertanian masih terjadi. (2) Masyarakat tidak mau melaporkan pelaku penebangan liar kepada pihak yang berwajib, penyuluhan tentang hutan yang diadakan pemerintah masih menemui kendala, masyarakat masih memanfaatkan kayu di hutan untuk berbagai keperluan. (3) Tidak semua masyarakat pernah melakukan penebangan liar dan berburu hewan di hutan, masyarakat sudah mau ikut serta dalam upaya menjaga kelestarian hutan mereka mau melakukan reboisasi atas kesadaran mereka sendiri meskipun tidak banyak masyarakat yang mau ikut (Komala, 1997).

Penelitian dari Maria Ulfa mengungkap "Hubungan Antara Pengetahuan Lingkungan dan Pendapatan dengan Perilaku Masyarakat Pada Kelestarian Lingkungan Cagar Alam Rimbo Panti Kabupaten Pasaman". Penelitian ini mengungkapkan bahwa perilaku masyarakat pada kelestarian lingkungan hidup tergolong rendah sebab sebagian besar responden mengelompokkan pada kategori rata-rata dan di bawah rata-rata. 2 pengetahuan lingkungan masyarakat tergolong sedang sebab bagian terbesar responden mengelompokan pada kategori rata-rata. 3 pendapatan masyarakat berada pada kategori rendah dimana sebagian besar responden mengelompokan pada kategori dibawah rata-rata, dimana pendapatan keluarga rata-rata $\mathrm{Rp} 481.000$ per bulan. 4 terdapat kolerasi yang signifikan dan positif antara pengetahuan lingkungan dengan perilaku masyarakat. 5 terhadap kolerasi yang signifikan dan positif antara kedua variabel bebas terhadap 
terhadap variabel prilaku masyarakat pada kelestarian lingkungan hidup dengan konstribusi sebesar $28,2 \%$ (Ulfa, 2018).

Selain itu penelitian dari Wahdini Dwiranda tentang "Pengetahuan Masyarakat Mengenai Tsunami dan Mitigasi Bencana Tsunami Di Kawasan Zona Merah" penelitian ini mengungkapkan bahwa pengetahuan lokal masyarakat mengenai tsunami, faktor pengetahuan masyarakat terhadap tsunami serta upaya menghadapi tsunami. Penelitian ini dipandu dengan kerangka fikir ethnoscience yaitu "system of knowledge and cognition typical of given culture" masyarakat yang tinggal dikawasan zona merah memiliki pengetahuan yang berbeda mengenai bencana tsunami (Dwiranda, 2013).

Penelitian yang dilakukan oleh Ratih Komala melihat perilaku masyarakat terhadap hutan hulu DAS. Penelitian yang dilakukan oleh Wahdini Dwiranda melihat tentang pengetahuan masyarakat mengenai tsunami dan mitigasi bencana serta penelitian yang dilakukan oleh Maria Ulfa berkaitan dengan judul Hubungan Antara Pengetahuan Lingkungan dan Pendapatan dengan Perilaku Masyarakat Pada Kelestarian Lingkungan. Penelitian yang dilakukan ini melihat masyarakat Nagari Unggan telah merusak keberadaan hutan yang menjadi ekosistem karena sebagian masyarakat memiliki mata pencaharian mereka berhubungan dengan hutan.

Jadi penelitian yang dilakukan ini berbeda dari penelitian sebelumnya karena memfokuskan pada pengetahuan masyarakat terhadap hutan (pelaku ilegal logging (somel) dan aktivitas-aktivitas yang berhubungan langsung dengan hutan, karena sistem pengetahuan merupakan hal yang paling dasar dan mendalam yang dimiliki oleh seseorang untuk menginterprestasikan lingkungan di sekitarnya termasuk hutan.

\section{Metode Penelitian}

Penelitian yang dilakukan di Nagari Unggan Kecamatan Sumpur Kudus Kabupaten Sijunjung pemilihan lokasi ini karena memiliki hutan luas yang menghasilkan kayu-kayu besar yang laku di pasaran. Masyarakat Nagari Unggan yang bertempat tinggal paling dekat dengan hutan lindung dan pada umumnya masyarakat Nagari Unggan ini bermata pencaharian sebagai petani karet dan pengolah kayu hutan untuk dijadikan kayu olahan. Alasan pemilihan tempat penelitian ini karena hutan lindung yang ada di Nagari Unggan seluas 20.576 ha dan sekarang telah rusak seluas 5.000 ha, karena ada aktivitas penebangan hutan yang dilakukan oleh masyarakat sekitar, sehingga hutan dengan segala ekosistem alam berserta biota yang ada terancam punah.

Pendekatan di dalam penelitian ini secara kualitatif, pendekatan kualitatif dipilih dengan pertimbangan jika menggunakan pendekatan ini maka permasalahan sosial sebagai sebuah proses penyelidikan untuk memahami masalah sosial atau masalah non sosial berdasarkan pada penciptaan gambaran holistik lengkap yang dibentuk dengan kata-kata, melaporkan pandangan informan secara terperinci, dan disusun dalam sebuah latar alamiah (Cresswell, 1998). Tipe Penelitian etnografi dilakukan untuk memahami pengetahuan masyarakat terhadap hutan dan juga dilakukan analisa etnografi dari Spradley (Spradley, 1997). Hal ini bertujuan agar interaksi antara peneliti dengan masyarakat yang diteliti bersifat sewajarnya, tanpa direkayasa sehingga perspektif emik bisa dipertahankan. Inti etnografi adalah mencoba memahami pengetahuan pelaku illegal logging terhadap hutan di Nagari Unggan Kecamatan Sumpur Kudus Kabupaten Sijunjung menurut pandangan mereka sendiri.

Pemilihan informan dilakukan secara (purposive sampling) yaitu menentukan informan dengan pertimbangan informan tertentu yang dipandang dapat memberikan data secara maksimal (Burhan, 2003). Menetapkan informan dengan sengaja sesuai, menentukan siapa yang menjadi informan penelitian sesuai dengan tujuan penelitian. Informan dalam penelitian yang dilakukan dengan kriteria terdiri dari masyarakat yang tinggal di sekitar hutan khususnya orang yang bergantung secara ekonomi dari hasil hutan terutama pengambilan dan pengolahan kayu karena secara tidak langsung mereka adalah orang-orang yang memiliki aktivitas sehari-hari bergantung

Culture \& Society: Journal of Anthropological Research Vol. 2, No. 2, Th. 2020 
pada kondisi hutan lindung serta orang-orang yang terlibat dalam aktivitas penebangan hutan. Hal ini karena mereka mengetahui kondisi hutan.

Setelah penelitian ini dilakukan, maka informan dalam penelitian ini berjumlah 43 orang yang terdiri dari 2 orang perangkat wali nagari (wali nagari, sekretaris nagari), 10 orang pemilik somel, 18 orang anak angkuik, 6 orang anak aghik dan karyawan somel, 3 orang anggota Polsek Sumpur Kudus (kapolsek, kepala SPKT dan unit intel), 1 orang Polisi Kehutanan, 1 orang Staf Kantor Dinas Kehutanan Kabupaten Sijunjung, 2 orang niniak mamak Nagari Unggan dan 1 orang guru surau. Studi dokumentasi ini berupa data mengenai kondisi geografis, demografis, bukubuku, artikel dan foto-foto untuk mempertegas hasil penelitian yang diperoleh yang peneliti temui. Analisis data kualitatif dalam penelitian ini adalah analisis yang dipopulerkan oleh James Spradley.

\section{Hasil dan Pembahasan}

Illegal logging adalah penebangan liar atau penebangan tanpa izin yang termasuk kejahatan ekonomi dan lingkungan, penebangan liar menimbulkan kerugian material bagi negara serta kerusakan lingkungan atau ekosistem hutan dan dapat dikenakan sanksi pidana dengan ancaman kurungan paling lama 10-15 tahun dan denda paling banyak Rp 5-10 miliar (UU No. 411999 tentang kehutanan, Pasal 78). Ketentuan pidana yang diatur dalam pasal 50 dan sanksi pidananya dalam pasal 78 UU No. 41 Tahun 1999, merupakan salah satu dari upaya perlindungan hutan dalam rangka dalam mempertahankan fungsi hutan secara lestari. Maksud dan tujuan dari pemberian sanksi pidana yang berat terhadap setiap orang yang melanggar hukum di bidang kehutanan ini adalah agar dapat menimbulkan efek jera bagi pelanggar hukum di bidang kehutanan (penjelasan umum paragraph ke 18 UU No. 41 Tahun 1999). Efek jera yang dimaksud bukan hanya kepada pelaku yang telah melakukan tindak pidana kehutanan, akan tetapi juga ditunjukan kepada orang lain yang mempunyai kegiatan dalam bidang kehutanan sehingga timbul rasa enggan melakukan perbuatan melanggar hukum karena sanksi pidana yang berat. Ada tiga jenis pidana yang diatur dalam pasal 78 UU No.41 Tahun 1999 yaitu pidana penjara, pidana denda dan pidana perampasan benda.

Illegal logging adalah masalah yang kompleks bagi pembangunan kehutanan namun menyadari arti pentingnya hutan bagi kelangsungan hidup umat manusia pada umumnya, masyarakat Kabupaten Blora dan bangsa Indonesia pada khususnya, maka mutlak hutan harus melakukan pelestarian hutan serta melindungi keberadannya demi kelangsungan hidup umat manusia itu sendiri, sehingga dapat mencegah aksi para pelaku illegal logging yang hanya mencari keuntungan pribadi semata (http://beritamanado.com/2010/01/15/).

Pengetahuan pelaku illegal logging di Nagari Unggan, dari hasil acuan dan observasi didapatkan gambaran tentang sistem pengetahuan atau pola pikir dari pemilik dan pekerja somel. Dari hasil penelitian terungkap bahwa menurut pengetahuan mereka hutan sebagai: A) pengetahuan tradisional pelaku illegal logging, (a) ritual di hutan, (b) pengetahuan tentang pohon, (c) pantangan di imbo (di dalam hutan), B) Pengetahuan pelaku illegal logging terhadap hutan, (1) hutan sumber uang, (2) sabolah kaki di kubugh sabolah kaki di panjaro, (3) piti palicin.

\section{Pengetahuan Tradisional Pelaku Illegal Logging}

Pengetahuan tradisional masyarakat Nagari Unggan tentang hutan tidak terlepas dari kehidupan masyarakat sejak dahulunya yang hidup berdampingan dan selaras dengan alam. Bagi mereka, hutan tidak hanya sebagai tempat tinggal makhlup hidup, tetapi sebagai karunia tuhan untuk masyarakat Nagari Unggan untuk menggantungkan hidup dan keluarganya. Sejak dahulu masyarakat Nagari Unggan, telah terbiasa hidup bergantung kepada alam termasuk hutan yang ada di sekitar mereka, secara tidak langsung generasi sebelumya telah mewariskan pengetahuanpengetahuan tradisional kepada anak cucu mereka tentang bagaimana mengolah hutan dan 
memanfaatkan hasil hutan untuk kesejahteraan tanpa membuat diri mereka celaka atau berada dalam bahaya.

\section{Hutan Ada Penghuni}

Pengetahuan tradisional masyarakat Nagari Unggan tentang hutan didapatkan dari nenek moyang mereka secara turun temurun yang disampai melalui lisan termasuk hal-hal gaib terutama makhlup-makhlup halus yang menguasai hutan, karena hutan adalah tempat tinggal bagi mereka. Cerita-cerita tentang makhlup halus yang menunggui hutan Nagari Unggan sudah menjadi cerita umum yang selalu dibicarakan, jika terjadi kejadian-kejadian aneh-aneh di hutan yang menimpa salah satu masyarakat yang sedang melakukan aktivitas di dalam hutan.

Pengetahuan tradisional tentang mitos penghuni hutan Nagari Unggan juga dimiliki oleh para pekerja somel, bahkan pengetahuan para pekerja somel lebih tinggi dan lebih luas tentang adanya penghuni yang menunggui hutan Nagari Unggan. Dari pekerja somel dari sejak zaman dahulunya atau pengambil kayu secara tradisional pada dahulunya sebelum ada alat somel, juga telah mengetahui dan memiliki cerita-cerita tentang mitos penghuni hutan nagari unggan. Hal tersebut membuat para pekerja somel sangat berhati-hati dan sangat memperhatikan sikap mereka ketika mengambil kayu di hutan.

\section{Ritual di Hutan}

Berdasarkan keyakinan masyarakat terhadap hutan terdapat ritual-ritual yang dipercaya masyarakat. Ritual-ritual tersebut masih dipercaya dan dijalankan oleh masyarakat Nagari Unggan hingga sekarang. Ritual-ritual tersebut menyangkut kehidupan sehari-hari masyarakat di hutan. Berikut ini penjelasan tentang ritual-ritual yang ada pada masyarakat Nagari Unggan yang berhubungan dengan hutan.

\section{Palongkaan (pelangkahan)}

Kepercayaaan terhadap palongkahan pertama memiliki pedoman palongkahan yang digunakan oleh pekarja somel untuk melangkah agar dia selamat pulang pergi. Pedoman palongkahan seperti peraturan mengenai hari-hari melakukan pekerjaan di hutan yang telah ditentukan jam berapa para pekerja somel harus berangkat menuju hutan.

Pedoman pelangkahan ini dipercayai memiliki kebenaran karena bisa meramalkan perjalanan yang ditempuh oleh para pekerja somel di hutan dalam berbagai kondisi seperti: 1) perjalanan yang mulia, 2) perjalanan yang membawa kemenangan, 3) perjalanan yang berbahaya, 4) perjalan yang mencintai dan dicintai, 5) perjalan yang tidak berbahaya, 6) perjalanan yang mendatangkan rezeki atau keuntungan, 7) perjalanan yang dimaksudkan untuk menemui seseorang atau mendapatkan sesuatu.

\section{Badoghan-doghan}

Banyaknya pantangan dan larangan yang diketahui oleh para pekerja somel terutama bagi anak aghik dan anak angkuik juga diiringi dengan pengetahuan mereka untuk mengatasi atau mencegah terjadinya marabahaya atau kecelakaan yang akan terjadi jika para pekerja somel mulai menebang kayu di hutan, hal ini dibuktikan dengan pengetahuan mereka tentang ritual yang harus dilakukan sebelum menebang kayu. Ritual yang dilakukan sebelum menebang kayu adalah badoghan-donghan, maksudnya kayu yang akan ditebang diberikan darah ayam yang sudah disembeli dan ditabur di sekitar lokasi penebangan kayu, darah ayam yang ditaburi ini sudah melalui proses pembacaan mantra-mantra yang dilakukan oleh orang yang juga memiliki ilmu dan pengetahuan tentang hal-hal gaib dan larangan didalam hutan.

\section{Tawagh Nan Ompek}

Menurut kepercayaan khususnya para pekerja somel yang mengetahui tentang penyebab sakit kasinggungan yang disebabkan oleh hal-hal gaib dan supranatural yang ada di dalam hutan, 
hanya bisa diobati atau disembuhkan dengan cara yang hampir sama yaitu ritual Tawagh nan ompek. Ritual ini digunakan apabila pekerja somel sakit-sakitan atau demam sesudah menebang kayu, ritual ini dilakukan dengan cara meminta pertolongan atau pengobatan pada orang yang diyakini sebagai orang pintar dan paham bahwa gejala penyakit kasinggungan merupakan penyakit non medis dan hanya dapat disembuhkan oleh pengobatan dengan cara non medis.

Penyakit kesinggungan bisa diobati oleh orang pintar yang diminta untuk melakukan ritual tawagh nan ompek, orang pintar akan membuat ramuan tawagh nan ompek yang kemudian membawa ramuan tersebut ketempat yang diyakini sebagai lokasi penebangan kayu yang membuat salah seorang pekerja somel mendapat penyakit kasinggungan. Setelah sampai di lokasi yang diyakini sebagai tempat pasien diganggu oleh hantu kayu, maka orang pintar akan memulai ritual dengan cara menaburi ramuan tawagh nan ompek yang disertai mantra-mantra agar antu kayu dari pohon yang telah ditebang tidak lagi menganggu dan memaafkan kesalahan para pekerja somel yang telah menganggu dan merusak tempat tinggal mereka.

\section{Pengetahuan Tentang Pohon}

Para pemilik dan pekerja somel tidak hanya mengetahui hal-hal yang berkaitan tentang hutan seperti pantangan dan ritual, namun hal yang paling penting selain itu mereka harus mengetahui hal-hal seputar pohon yang akan diolah. Pengetahuan tentang pohon-pohon yang akan diolah sangat penting bagi pekerja somel, karena menentukan hasil dan kualitas kayu yang didapatkan. Pengetahuan tentang pohon biasanya didapat dari pengalaman selama bekerja di somel yang lebih senior (yang lebih dahulu).

\section{Dagiang kayu}

Serangkaian kegiatan yang dilakukan oleh pekerja somel agar mendapatkan kayu dengan kualitas yang super adalah mengecek dagiang kayu dari pohon yang telah dipilih oleh tim survei. Tim survei akan melaporkan kepada tim yang akan membuka galang untuk penebangan kayu, namun sebelum hal itu dilakukan, tim survei telebih dahulu akan mengecek kualitas dari dagiang kayu yang akan ditebang.

Menurut pengetahuan pekerja somel hasil cek dagiang kayu dapat memperlihatkan kualitas dari suatu pohon. Biasanya sekitar 2 orang pekerja somelakan mengambil sampel batang kayu dengan salah satu mesin shinso dengan ukuran tertentu (jika ukuran potongan yang diambil sudah dapat menunjukan kulitas dari sampel dagiang kayu). Jika tebangan mesin shinso telah memperlihatkan warna dagiang kayu dari pohon yang akan ditebang, maka tim baru bisa memutuskan apakah pohon yang telah dipilih oleh tim survei memiliki kualitas yang bagus.

\section{Umur Kayu}

Pengetahuan pemilik dan pekerja somel tentang pohon yang akan ditebang juga termasuk umur pohon yang telah ditebang. Pekerja somel mentaksirkan umur sebatang pohon yang telah ditebang dari cincin pohon. Cincin pohon yang terbentuk menunjukan umur pohon yang telah ditebang, umur pohon yang telah ditebang oleh para pekerja somel tidak ditentukan atau tidak bisa dinilai dari ukuran batang pohon (panjang ataupun lebar), tetapi dinilai dari banyaknya cincin yang terbentuk seperti lapisan-lapisan.

\section{Batang kayu luwi (lurus)}

Struktur dan bentuk setiap jenis pohon yang akan ditebang oleh pekerja somel akan mempengaruhi hasil kayu yang telah diolah dan memiliki kualitas yang bagus. Kayu dengan kualitas yang bagus memiliki batang atau struktur yang lurus atau tidak bengkok, karena hal ini mempengaruhi pada saat proses pengolahan dan bentuk kayu setelah diolah. Biasanya tim survei ketika memilih pohon yang akan ditebang tidak hanya melihat besar pohon, warnah daging pohon, tetapi juga akan melihat bentuk dan struktur pohon.

Pohon dengan struktur yang tidak lurus akan mempengaruhi proses pengolahan kayu, karena anak aghik akan mengalami kesulitan pada saat pengerjaan kayu dan pengolahan mulai 
dari membuka kulit kayu, memotong menjadi balok-balok, hingga menjadi kayu yang siap dijual. Di pasaran kayu hasil olahan somel telah memiliki beberapa ukuran dan standar, jika pohon yang akan diolah tidak memiliki struktur batang yang lurus maka akan banyak kayu yang tersisa dan menjadi sebiran. Akibat dari mengolah batang pohon yang tidak lurus membuat sebiran dari hasil olahan kayu menjadi banyak, hal ini tentu membuat para pekerja somel mendapat keuntungan sedikit, karena kayu yang seharus bisa dijual mahal menjadi dijual murah, karena kondisi kayu yang tidak lurus. Berikut ini penuturan dari beberapa pekerja somel yang berkaitan dengan kayu sebiran.

\section{Pantangan di Imbo (di dalam hutan)}

Kondisi mayarakat Nagari Unggan sebagian besar menggantungkan mata pencaharian mereka terhadap hasil hutan. Pemilik dan pekerja somel harus bekerja keras melakukan proses pengolahan mulai dari mencari lokasi pohon yang akan ditebang, memotong-motong pohon menjadi beberapa bagian yang dapat diangkut serta pengolahan dari kayu setengah jadi, menjadi beberapa produk olahan, untuk proses yang dilewati oleh para pekerja somel di dalam hutan.

\section{Manobang Kayu Gadih dan Manyobuik Podiah Powik Jo Awi}

Dalam menjalankan profesi sebagai pemilik somel ataupun pekerja somel harus terlebih dahulu mengetahui segala sesuatu yang berkaitan tentang hutan mulai dari pohon yang layak ditebang, bahkan sampai larangan yang tidak boleh dilakukan jika berada di hutan. Masyarakat Nagari Unggan khususnya pekerja somel masih mempercayai segala sesuatu pantangan serta larangan yang tidak boleh dilakukan ketika berada di hutan. Menurut beberapa pekerja somel hutan masih menjadi tempat yang menakutkan dan berbahaya jika diri tidak waspada baik yang berhubungan dengan hal-hal gaib ataupun yang berhubungan dengan kondisi yang berbahaya. Untuk itu para pekerja somel telah mengetahui pantangan dan larangan tertentu seperti larangan untuk tidak membicarakan kata-kata tertentu yang berbau mistis menurut anak aghik.

\section{Kulik koniang imau (kulit kening harimau)}

Adanya kepercayaan terhadap atuak atau harimau sebagai penguasa hutan membuat para pekerja somel mencari menangkal bahaya yang akan dihadapi, walaupun bersifat mitos atau tahayul. Sebagian besar para pekerja somel memiliki jimat pelindung yang diyakini dapat menangkal dan melindungi mereka dari bahaya binatang buas termaksud harimau baik yang nyata maupun harimau jadi-jadian (makhluk halus yang dipercayai jadi harimau).

Keyakinan dan kepercayaan terhadap jimat dari kulit harimau juga dikuatkan oleh bahan dasar dari jimat ini berasal dari bagian tubuh harimau yang telah mati dan diambil kulitnya, terutama kulit harimau yang diawetkan. Dalam pola pikir para pekerja somel, atuak atau harimau akan takut kepada para pemilik jimat harimau, karena orang yang memiliki jimat diyakini mampu membunuh harimau. Menurut cerita yang dituturkan oleh para pekerja somel jika seseorang memiliki jimat kulit harimau maka dari jarak yang cukup jauh harimau mampu mencium aroma kulit harimau yang dia simpan, hal ini membuat harimau takut dan menghindari pemilik jimat kulit harimau.

\section{Ughang Bunian Ma Ompen Kain}

Aktivitas para pekerja somel dalam menebang kayu juga harus memperhatikan kondisi lingkungan tempat mereka bekerja, termasuk kondisi cuaca pada waktu itu. Hal ini dilakukan karena para pekerja somel memiliki kepercayaan bahwa dilarang (pantang manobang kayu) ketika cuaca disekitar lokasi terlihat seperti ughang bunian ma ompen kain. Maksud dari ughang bunian ma ompen kain adalah suatu kepercayaan para pekerja somel terhadap hal gaib yang disimbolkan atau ditandai dengan cahaya matahari pada sore hari yang menyinari beberapa pohon yang berada di hutan, sedangkan cuaca di tempat lain terlihat gelap atau tidak ada sinar matahari.

Jika kondisi cuaca diyakini sebagai pertanda ughang bunian ma ompen kain, maka para pekerja somel akan segera memberhentikan pekerjaan mereka, kerena takut para orang bunian

Culture \& Society: Journal of Anthropological Research Vol. 2, No. 2, Th. 2020 
akan marah dan menganggu pekerjaan penebangan dan pengolahan kayu. Orang bunian yang dimaksud oleh para pekerja somel adalah penyebutan untuk mahkluk-mahkluk supranatural atau roh-roh gaib yang mendiami lokasi di sekitar tempat pengambilan kayu. Jadi ketika cuaca memberikan isyarat seperti kepercayaan terhadap orang bunian, maka ini merupakan petanda yang diyakini oleh para pekerja somel untuk memberhenti atau istirahat sejenak dari pekarjaan mereka untuk menghormati para penunggu dan roh-roh yang dipercayai menguasai hutan, jika tidak maka hal-hal aneh atau kecelakaan bisa terjadi kepada para pekerja somel.

\section{Pengetahuan Pelaku Illegal Logging Terhadap Hutan}

Berbeda dengan pengetahuan tradisional masyarakat tentang hutan Nagari Unggan, pengetahuan pelaku illegal logging terhadap hutan merupakan pengetahuan yang berkaitan dengan pengetahuan yang khas yang dimilik oleh pelaku illegal logging, karena aktivitas mereka yang mengelolah hutan, mengambil hasil hutan, kemudian mengolah kayu yang diambil di hutan untuk dijual dan di pasarkan. Sebenarnya aktivitas masyarakat tersebut melanggar hukum dan undangundang, sehingga demi keberlansungan hidup keluarganya, para pekerja somel tetap melakukan aktivitas mengolah kayu di hutan.

\section{Hutan Sumber Uang}

Banyak aktivitas masyarakat yang mengolah hutan hanya memikirkan keuntungan pribadi dan kelompok jangkak pendek seperti memperkaya diri sendiri, sebagai mata pencaharian. Hal yang sama juga terjadi di Nagari Unggan Kecematan Sumpur Kudus Kabupaten Sijunjung. Masyarakat di Nagari Unggan juga sangat tergantung kepada hasil hutan karena sebagian besar dari masyarakat mata pencaharian sehari-hari tidak terlepas dari aktivitas mengolah hasil hutan pemilik somel dan pekerja somel.

Kayu olahan somel biasanya dalam berbagai bentuk seperti lember dan profil. Harga kayu yang masih dalam keadaan balok lebih murah bahkan terkadang tidak laku dijual kecuali jika pengusaha somel telah melakukan pengolahan lebih lanjut menjadi lember dan profil. Harga lember dan profil biasanya bisa mencapai Rp 12.000/helai, harga kayu olahan inilah yang membuat para pengusaha somel menggantungkan mata pencaharian mereka pada usaha somel. Selain faktor harga jual kayu olahan somel yang mahal alasan lain yang membuat masyarakat Nagari Unggan menjadikan somel sebagai matapencaharian adalah tidak ada pekerjaan lain yang bisa menghasilkan uang yang banyak seperti penghasilan pekerja di somel atau pun usaha menjalankan somel serta masyarakat telah memiliki skill dalam hal mengolah kayu untuk lember dan profil.

\section{Sabolah Kaki di Panjaro Sabolah Kaki di Kubugh}

Para pemilik dan pekerja somel memang mendapatkan keuntungan yang sangat besar dari hasil mengolah kayu di hutan Nagari Unggan keuntungannya dalam per kubik kayu mulai dari Rp 400.000 sampai Rp 600.000. Hal ini juga sejalan dengan tantangan dan resiko yang ditanggung oleh para pekerja somel dan pemilik somel. Mulai dari sakit akibat bekerja (memindahkan kayu dari dalam hutan), meninggal (kecelakaan pada saat bekerja) dan di bui (masuk penjara karena tertangkap melakukan illegal logging).

Para pekerja somel dalam menjalankan pekerjaannya memiliki tantangan yang sangat keras ketika berada di dalam hutan. Tantangan berasal dari pekerjaan yang sedang dilakukan, karena setiap proses pengolahan kayu memberikan peluang untuk terjadi kesalahan atau kecelakaan yang dapat membuat para pekerja kapan saja bisa kehilangan nyawanya.

Tantangan yang pertama yaitu ketika pohon besar yang akan diolah menjadi balok-balok kayu ditebang di sekitar area galang dengan menggunakan mesin shinso sangat beresiko, karena jika salah perhitungan arah jatuhnya pohon yang ditebang akan melukai para pekerja yang berada disekitar lokasi jatuhnya pohon. 
Dari para pekerja somel yang terluka akibat kesalahan pada saat menebang pohon, baik karena para pekerja tidak waspada terhadap arah jatuhnya pohon yang ditebang maupun salah perhitungan dalam memperkirakan posisi jatuhnya pohon.

\section{Piti Palicin}

Para pemilik somel dan para pekerja somel akan selalu bermasalah dengan hukum karena pekerjaan merekabagian dari illegal logging, sehingga untuk terbebas dari jerat hukum berbagai upaya dan usaha mereka tempuh agar usaha mereka tetap berjalan tampa diketahui oleh pihak yang berwenang (Dinas Kehutan dan Kasat Reskrim Polisi). Usaha yang dilakukan oleh pemilik dan pekerja somel agar terhindar dari pada penegak hukum salah satunya bermain uang (piti palicin).

Ternyata dibalik usaha somel yang ada di Nagari Unggan terdapat oknum-oknum yang memberikan pelindungan terhadap pekerjaan illegal logging ini, sehingga hanya sedikit para pemilik somel beserta barang bukti yang berhasil ditangkap oleh pihak yang berwajib. Perlindungan yang diberikan oleh para oknum kepada para pemilik somel seperti analogi simbiosis mutualisme artinya hubungan para pemilik somel dan oknum memiliki hubungan yang saling menguntungkan, karena pemilik somel mendapatkan keamanan dan jaminan usaha mereka, sedangkan para oknum mendapatkan uang suap dari para pemilik somel sebagai imbalan atas jasa keamanan yang mereka berikan.

\section{Analisa Etnosain terhadap pengetahuan Illegal Logging Mengenai Hutan}

Etnosains bertitik tolak dari bagaimana masyarakat melukiskan lingkungan sebagaimana dilihat oleh masyarakat setempat, yakni dengan cara mengungkapkan taksonomi-taksonomi dan pengklasifikasian yang ada dalam istilah lokal, karena dalam bahasa atau kata-kata yang diucapkan oleh masyarakat terdapat makna dan pengetahuan mereka tentang lingkungannya. Dengan cara demikian dapat diketahui hubungan masyarakat dan lingkungan benar-benar dipersepsikan oleh suatu kelompok manusia dengan pengetahuan yang sendiri sehingga sesuai dan dianggap tepat oleh masyarakat yang diteliti.

Dapat diketahui hubungan masyarakat dan lingkungan benar-benar dipersepsikan oleh suatu kelompok manusia dengan pengetahuan yang mereka miliki sendiri sehingga sesuai dan dianggap tepat oleh masyarakat yang diteliti.

Pengetahuan tradisional yang dimiliki oleh masyarakat dapat memberikan informasi yang sangat berguna dan bernilai karena pengetahuan ini memberi informasi awal tentang lingkungan mereka (Daulay, 2011).

Peneliti menganalisis permasalahan pengetahuan pelaku illegal logging terhadap hutan memakai aliran teori antropologi ekologi kognitif, karena melihat hubungan timbal balik dan adaptasi manusia dengan lingkungannya. Aliran ini pertama kali dipopulerkan oleh Julian Steward, seorang ahli yang pertama kali menyarankan pengkajian tentang ekologi kebudayaan, yaitu analisa mengenai hubungan antara suatu kebudayaan alam dengan sekitarnya atau lingkungannya. Steward merasa bahwa penjelasan untuk beberapa aspek-aspek variasi kebudayaan dapat dicari dalam adaptasi masyarakat terhadap lingkun

Asumsi dasarnya adalah bahwa setiap masyarakat mempunyai satu sistem yang unik dalam mempersepsikan dan mengorganisasikan fenomena material, seperti benda-benda, kejadian, perilaku, dan emosi. Karena itu, objek kajian antropologi (kognitif) adalah menemukan dan menggambarkan organisasi pikiran (mind) manusia. Dalam etnografi baru (etnosains) bentuk tersebut dianggap sebagai susunan yang terdapat dalam pikiran (mind) anggota masyarakat tersebut.

Tugas dan cara peneliti mengoreknya keluar lalu mendeskripsikannya adalah khas metode dari etnosains. Berdasarkan perspektif teori ini penulis menggali pengetahuan masyarakat Nagari Unggan Kecamatan Sumpur Kudus Kabupaten Sijunjung terhadap hutan 


\section{Gambar 1. Peta Kognitif pengetahuan somel}

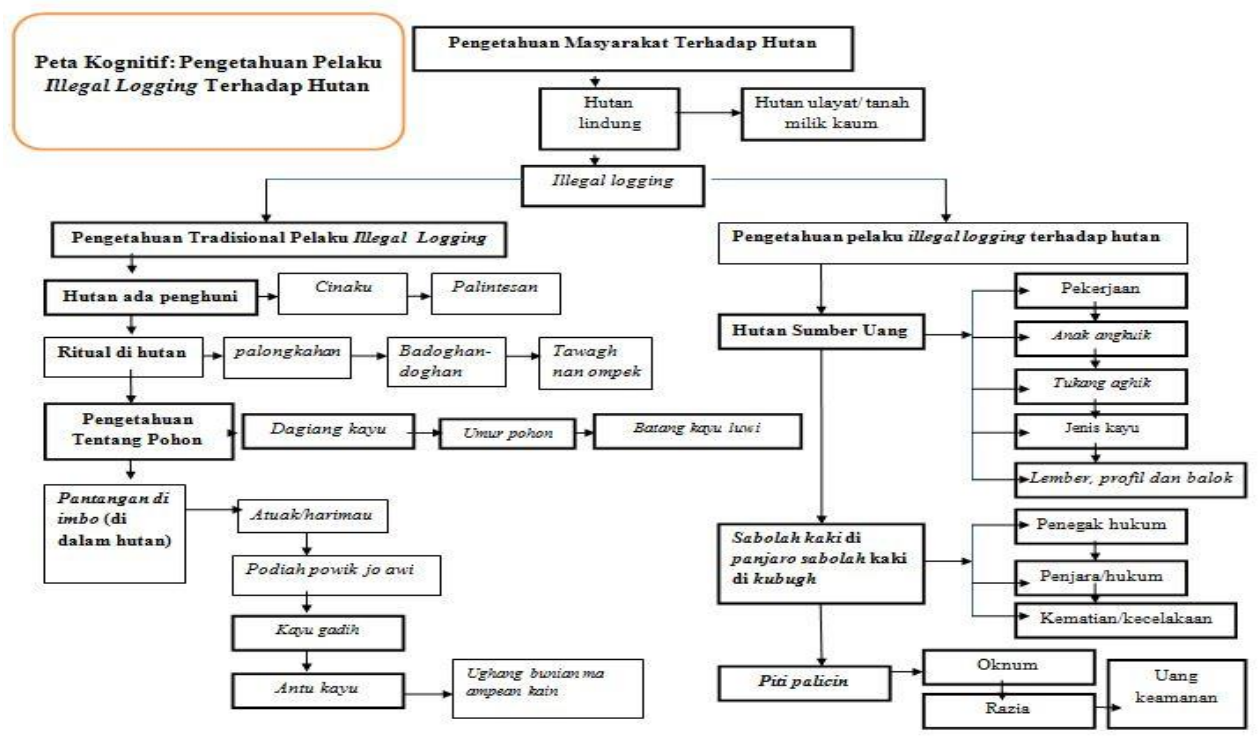

\section{Kesimpulan}

Pengetahuan tradisional pelaku illegal logging, pertama para pekerja somel mengetahui ritualritual yang harus dilakukan ketika berada di hutan, kedua mereka memiliki pengetahuan tentang pohon yang ada di hutan, ketiga dalam menjalankan pekerjaan mereka mengetahui pantangan di imbo (di dalam hutan), keempat para pelaku illegal logging menganggap hutan sebagai sumber uang, pekerjaan mereka memiliki tantangan mempertaruhkan nyawa (sabolah kaki di panjaro sabolah kaki di kubugh), keenam agar pekerjaan mereka berhasil, mereka bekerja sama dengan oknum (piti palicin). Pengetahuan pelaku illegal logging (pekerja somel) terhadap hutan merupakan hasil interprestasi mereka dari pengalaman selama bekerja sebagai pekerja somel.

\section{Daftar Rujukan}

Asoka, A. (2011). Eksploitasi Hutan di Sumatera Barat 1915-1942. Padang: Minangkabau Press.

Burhan, B. (2003). Metode Triangulasi. Di dalam Analisis Data Penelitian Kualitatif. Pemahaman Filosofi dan Metodologis Kearah Penguasaan Model Aplikasi. Jakarta: PT Raja Grafindo Persada.

Cresswell, J. (1998). Research Design: Qualitative and Quantitative Approaches. CA: Sage Publications.

Daulay, Zailul. 2011. Pengetahuan Tradisional: Konsep, Dasar Hukum dan Praktiknya. Jakarta: PT Raja Grafindo Persada

Dwiranda, W. (2013). Pengetahuan Masyarakat Mengenai Tsunami dan Mitigasi Bencana Tsunami Di Kawasan Zona Merah. Universitas Negeri Padang.

Haffar, Z. (1997). Peranan Nilai Budaya Daerah dalam Pelestarian Lingkungan Hidup di Jambi. Jambi: CV. Lazuardi.

http://www.Berita kota .net/indeks.php/2010/05/03. pembalakan liar vs gerakan menanam kembali. Diakses pada tanggal 10 September 2014.

http://grennch.multiply.com/journal/item/8 diakses pada tanggal 10 September 2014.

http://www.sijunjung.go.id/?mod=konten\&menu=kehutanan diakses 20 Desember 2014. 
http://www.sumbarprov.go.id/read/99/12/14/59/79-mengenal-sumbar/berita-terkini/1123dishut-sumbar-melakukan-mitigasi-bencana-dalam-kawasan-hutan.html diakses pada tanggal 23 April 2015.

Komala, R. (1997). Prilaku Masyarakat Terhadap Hutan Hulu DAS Batang Kuranji Batu Busuk Kecamatan Pauh Kota Padang. Universitas Negeri Padang.

Marpaung, Leden. (1995). Tindak Pidana Terhadap Pembalakan Hutan dan Satwa. Jakarta: Erlangga. Moleong, Lexy J. (2005). Metode Penelitian Kualitatif. Bandung: PT. Remaja Rosdakarya

Riyanto, Eggi. (1999). Penegakan Hukum Lingkungan Dalam Perspektif Etika Bisnis di Indonesia. Jakarta: Gramedia Pustaka

Sugiyono, S. (2012). Metode Penelitian Kuantitatif KualitatifDan R\&D. Bandung: Alfabeta

Spradley, J. P. (1997). Metode Etnografi. Yogyakarta: PT Tiara Wacana Yogya.

Ulfa, M. (2018). Persepsi Masyarakat Nelayan dalam Menghadapi Perubahan Iklim (Ditinjau dalam Aspek Sosial Ekonomi. Jurnal Pendidikan Geografi, 23(1), 41-49. https://doi.org/10.17977/um017v23i12018p041

Poerwanto, Hari. 2005. Kebudayaan dan Lingkungan Dalam pesrfektif Antropologi. Yogyakarta: Pustaka Pelajar

Widjaya, W. 1985. Pembalakan Hutan Indonesia. Jakarta: Sinar Grafika.

\section{Penjelasan Istilah:}

1. Anak angkuik adalah istilah yang dipakai oleh orang-orang yang terlibat dalam usaha somel khususnya bagi mereka yang bertugas memindahkan kayu dari dalam hutan ke tempat pengolahan kayu.

2. Anak aghik adalah istilah untuk orang yang bertugas menebang pohon lalu memotong pohon menjadi ukuran balok-balok.

3. Tawagh nan ompek adalah sejenis dedaunan yang ditaburi di sekitar pohon yang akan ditebang yang terdiri dari 4 jenis daun daun sitawagh, daun sikoghow, daun sikumpai dan daun sidingin.

4. Cincin pohon adalah istilah yang digunakan oleh para pekerja somel untuk menjelaskan linkaranlingkaran yang terbentuk secara alamiah di dalam batang pohon, biasanya cincin pohon dapat terlihat ketika sebatang pohon ditebang lurus.

5. Sebiran adalah istilah yang sering dipakai oleh para pekerja somel untuk menyebutkan kayu-kayu sisa potongan yang tidak sesui ukuran, kayu sebiran ini memiliki struktu yang tidak lurus seperti bengkok, sehingga para pekerja somel hanya bisa menjual dengan harga yang jauh lebih murah. Kayu sebiran ini memiliki kualitas yang tidak bagus karena lebih tipis. Kayu sebiran biasanya digunakan oleh masyarakat untuk membuat kandang ayam, kotak-kotak pengangkutan buah.

6. Lember dan profil adalah kayu olahan somel yang biasanya digunakan oleh masyarakat sebagai bahan bangunan seperti dinding variasi.

7. Balok adalah kayu yang baru diambil di hutan namun belum mengalami proses pengolahan, biasanya kayu balok adalah batang pohon yang dipotong-potong yang menjadi beberapa bagian untuk memudahkan pemindahan kayu ke pabrik pengolahan.

8. Galang adalah istilah untuk lokasi pertama tempat kayu ditebang kemudian di olah menjadi balok-balok kayu, biasanya daerah yang berada di sekitar galang dibabat untuk merapaikan pohon-pohon yang diperkirakan akan menghambat proses pengolahan kayu, sehingga pohon-pohon kayu kecil yang bersada di sekitar area galang akan ditebang, besarnya area galang tergantung besarnya pohon yang akan ditebang, maka semakin besar pohon yang ditebang maka area galang juga akan semakin luas.

9. Piti palicin adalah uang suap yang diberikan kepada pihak-pihak tertentu yang bisa menjamin jalanya usaha para pekerja somel terutama dalam memberikan keamanan kepada pemilik somel dan kayu-kayu yang dikirim keberbagai daerah dengan menggunakan pihak keamanan sebagi pengiring. 